\title{
EMPLOYERS' AND EMPLOYEES' UNDERSTANDING OF OCCUPATIONAL HEALTH AND SAFETY RISKS IN SMALL BUSINESSES: A CASE STUDY
}

\author{
Bikram R Pandey \\ Ian S. Laird \\ Kirsten B. Olsen \\ Peter Hasle \\ Stephen J. Legg \\ Centre for Ergonomics, Occupational Health and Safety
School of Management
Massey University, Palmerston North.
}

\begin{abstract}
Many small businesses have hazardous work environments and exposures to significant occupational health and safety risks. Differences in understanding of risks by employers and employees are one of the factors leading to the hazardous work environment and risk exposures in small businesses. Employees generally describe "the tools of the trade" as the sources of risks of accidents and injuries, whereas employers generally identify "bad employees" or "bad luck" as the cause of accidents. It seems that employer and employees having the same or a shared understanding of occupational health and safety problems, their causal relations and the course of action is essential to remedy the work environment problems in the workplace. This paper describes a study that explores owner/managers' and employees' understandings of occupational health and safety risks in small business workplaces within the framework of the Local Theory of Work Environment. A case study of an independently operated restaurant and café in New Zealand employing 6-19 employees was undertaken.. Data was collected using participant-as-observer ethnographic observation of the workplace followed by semi structured interviews of the owner, a manager and more than fifty per cent of employees employed in the business. Preliminary findings based on interview data are reported in this paper. The results suggest that the owner/manager and employees mainly consider physical safety problems experienced by employees or food safety problems affecting the customers as the key work environment problems. The owner/manager and employees generally link common sense and breach of norms with the causal relation behind these problems. Social exchange and external certification, among others, are found to be prominent reasons for bringing to attention the perceived problems in the wider work environment context. Implicit individual element of action and explicit organizational element of action are recognised as the two courses of action remedying the occupational health and safety problems. Further studies can be directed at finding how a shared understanding of the OHS risks occurs and what influences this process.
\end{abstract}

\section{Introduction}

Small businesses (SBs) are particularly recognised as having hazardous work environments that potentially expose people at work to occupational health and safety (OHS) risks (Sorensen, Hasle, \& Bach, 2007). Some of the reasons for the hazardous work environment are: limited availability of resources (Champoux \& Brun, 2003; Hasle \& Jensen, 2006; Hasle \& Limborg, 2006), limited coverage to adequately prepare and provide small businesses with necessary tools and techniques for compliance with existing regulatory policies (Lamm, 2002; Legg, et al., 2009) and difficulty for external agencies in getting access to make any interventions possible to influence change in the existing conditions (Hasle, 2009). In addition to these issues, differences in what employers and employees, as two primary social groups, perceive as the work environment problems, and

the causes behind these, contribute equally to the condition of exposures to hazardous work environments (Holmes \& Gifford, 1997). Employees generally describe "the tools of the trade" (i.e. the chemicals and equipment) as the sources of occupational health and safety risks producing ill health and injuries (Holmes \& Gifford, 1997; Lingard \& Holmes, 2001). Employers generally ascribe OHS risks to "bad employees" and their "work attitudes" such as incorrect work practices, lack of knowledge and negligence which contribute to accidents, incident and injuries (Gardner, Cross, Fonteyn, Carlopio, \& Shikdar, 1999; Hasle, Kines, \& Andersen, 2009; Holmes, Triggs, Gifford, \& Dawkins, 1997). Even in instances where employers and employees seem to have similar understanding of the causes of OHS risks, either they blame the employees and ascribe the causes of 
accidents and injuries to "careless workers failing to take responsibilities" (Holmes, et al., 1997) or attribute workplace accidents to "unforeseeable circumstances" or "bad luck" (Hasle, et al., 2009). However, ascribing injuries and accidents either to employees or unforeseeable circumstances is unhelpful in prevention and control of OHS risks mainly because such ascription principally rejects the general concept that circumstances under control are the causes behind OHS risks (Hasle, et al., 2009). Therefore, in small businesses in particular, it seems that control of OHS risks is concerned with developing a shared understanding of the work environment problems between employers (owner/manager) and employees. A shared understanding is articulation of what the owner/manager and employees, as social groups, understand as OHS risks or the work environment problems, the causes behind the problems, the reasons for articulation of the problems and the courses of action for rectifying the work environment problems in the wider work environment context (Jensen, 2002).

Restaurants and cafes are a particular type of small business with unique contexts in relation to OHS which are little studied. Restaurants and cafés combine elements of simultaneous production/transformation, service and consumption in their operations with customers as active participants in the process. Meeting the needs of customers, involved in the production/transformation process, requires a combination of a wide range of activities with a high degree of coordination (Mullins, 1993). Such requirements often involve long and 'unsocial' hours of work under time pressures. Combination of these factors contribute to increased diversity and severity of OHS risks already caused by existing physical, chemical or other factors in the work environment. But it is a sector with special difficulty in controlling the OHS risks due to, among other reasons, the temporary and part time nature of employment (Ryan, 1996). Thus it is relevant to study owner/managers' and employees' understanding of OHS risks in this sector and the development of a shared understanding of risks by these key social groups, which will add to the general knowledge about controlling OHS risks in small businesses.

This paper therefore examines the understanding of OHS risks by owner/manager and employees in small business and whether a shared understanding of OHS risks is developed between these social groups.

\section{Theoretical Background}

Understanding of risk can be explained at three levels Expert based understanding; Legal understanding; and Local understanding (Jensen, 2002). The expert based understanding of risk is the quantitative product of the probability of occurrence of an undesirable event and the consequences of such an event (Jensen, 2002; Renn, 1992). The legal understanding of risk is the descriptive/prescriptive definition of risks outlined in a country's regulations. The legal understanding of risks relies on the political processes of compromise or consensus among various stakeholders on defining risks. The local understanding of risks is a shared understanding of risks established between social groups within the context of the local work environment and has been conceptualised as the Local Theory of Work Environment (Jensen, 2002).

Local Theory of Work Environment (LTWE) was developed by Sørenson and Sætnam (1983). The LTWE is formulated on four interdependent elements pertaining to the cause-effect relationship of the work environment problems or OHS risks (Jensen, 2002). The four elements of OHS risks are: i. Elements of Experience, ii. Theoretical-Analytical Element, iii. Legal-Moral element, and iv. Element of Action. The Local Theory of Work Environment suggests that mutual understanding of these four elements between the social groups is a precondition for any positive action taken on OHS risks in the work environment (Jensen, 2002). Usually OHS risk prevention activities are considered in the interest of employees and against the profit motive of owner/managers (Walters \& Frick, 2000). Thus, a shared understanding of the four elements of the cause-effect relationship of OHS risks shapes controlling of risks in the workplace.

The 'Elements of Experience' refers to what is experienced or considered as work environment problems.

The 'Theoretical-analytical elements', referred to as 'Elements of causal relation', pertains to what the social groups consider to have caused the work environment problems.

The 'Legal-moral elements', referred to as 'Elements of legitimisation', pertains to the reasons that make it legitimate to bring to attention work environment problems or the reason for not doing so.

The 'Element of action' pertains to the social groups' understanding of the courses of action to remedy the work environment problems or their understanding of how the problems can be solved.

This paper therefore explores the understanding of OHS risks by owner/managers and employees and the extent to which they have a shared understanding of OHS risks using the framework of the Local Theory of Work Environment. Based on the four elements of the local theory of work environment, the paper investigates the owner/managers' and employees' understanding of OHS problems, the causal relation of the problems, arguments legitimising bringing up of the problems and the courses of action to rectify the problems..

\section{Methods}

This paper is based on a case study of a small restaurant and cafe in operation in the Central Region of the North Island, New Zealand. The case was purposively selected on the criteria that it should have a 6-19 employee count (EC), be independently owned, and should have been in 
operation for more than a year. As the interest of the present study is in small businesses the EC of between 6 and19, which is a widely used definition of small businesses (Massey, 2004, 2005), allowed positive selection of a small business. Similarly, independent ownership, as a criterion, allowed de-selection of franchises and chain restaurants and cafes despite falling within the definition of small businesses. Unlike independently owned small businesses, franchise and chain restaurants and cafes are assumed to have formal OHS practices in place governed by their respective parent organization. Lastly, the length of time in operation, set at a minimum of one year, is considered to have allowed selection of a small business with stable employment relations and operational practices that included OHS.

Participation of the business in the study was first confirmed through initial telephone contact with the owner. After the owner's initial consent to participate, a visit was organized during which time the purpose of the study, the study method and my involvement in the business as an observer was explained. This followed presenting a schedule for data collection to the owner. Suitability of the proposed schedule in relation to the staff roster was confirmed through another round of telephone conversations.

\section{Data Collection}

Data collection involved semi structured interviews and participant-as-observer ethnographic field observations. The owner of the participating SB was interviewed at the beginning of the data collection process. This was followed by ethnographic field observations. Finally, interviews with the employees and the manager completed the process of data collection. This paper, however, reports only on the findings of the semi structured interviews.

An interview guide outlining the main areas of enquiry prepared beforehand guided the interviews and allowed in depth enquiry into the area of interest (Kvale, 1996). The interview guide outlined the following main issues:

- The good things about work environment

- OHS hazards and risks in the work environment

- How people come to know about hazards and risks

- How the hazards and risks are dealt with

- Who was involved in dealing with risks

- Description of any incident that has happened

- The Way the incident was/is dealt with

Interview questions were asked in no particular order. The owner, a manager, and employees from both the kitchen and the restaurant floor participated in the interviews. Interviews were undertaken on the premises and a verbal consent for interview was obtained from each interviewee prior to actual interview.

Interviews ranged from 12 to 45 minutes. On average the interviews were 24 minutes long. The interview responses were digitally recorded the responses were transcribed verbatim using an Olympus DSS Transcription Module.

The study received ethical approval for research involving human subjects from Massey University Human Ethics Committee, MUHEC. The human ethics application included samples of information sheets and participant consent forms, and separate lists of possible interview questions for owner/manager and employees groups.

\section{Data Analysis}

The interview data were subjected to thematic analysis. Thematic analysis is a method for identifying, analysing and reporting patterns (themes) within data as accomplished in six stages: familiarisation with data, generating initial codes, reorganizing initial codes, categorising, identifying potential themes and developing themes (Braun \& Clarke, 2006). To familiarise with the data the interview responses were read and re-read noting down threads of responses relevant to the four elements of LTWE. The threads of responses sought for each element of local theory of work environment, were:

Elements of experience - hazards, injuries or identified risks of injuries and incidents;

Elements of causal relations - anything that the respondents mentioned as the causes behind the hazards, injuries or risks of injuries and incidents;

Elements of legitimisation - reasons, either verbally spelt out by the respondents or collated from within the data, for bringing into discussion the hazards, injuries or risks of injuries;

Elements of action - respondents' opinion about possible measures that can minimise work environment problems, or the measures taken to minimise the work environment problems, or the way things are done to control hazards, injuries and risks of injuries.

The threads of responses noted down generated the initial codes and were entered in NVivo. The initial codes were entered under the corresponding interviewee as a tree node. From these initial codes, common threads of responses that closely characterised the elements of the LTWE were identified and grouped together. The grouping of common threads of responses from owner/manager and employees was done side by side. The regrouped common threads were developed into categories based on the characteristics that the threads of responses commonly described. From these categories sub themes that closely summarise the characteristics of the categories were developed. The sub themes also indicated potentially emergent themes.

\section{Results}

\section{Description of the case}

The business has been in operation for one and a half years employing 13 employees, all of which are in permanent part time employment. Of these employees, 6 work in the kitchen and 7 on the restaurant floor and in 
reception. The owner is designated as the executive chef and working in the kitchen.

\section{Understanding of OHS risks}

Owner/managers' and employees' understanding of OHS risks as characterised by the four elements of the Local Theory of Work Environment, or LTWE, are presented in tables from Table 1 to Table 4. The first and second columns of the respective tables present the descriptions by owner/manager and employees of OHS problems, causal relations of the problems, arguments legitimising bringing up of the problems and the courses of action understood as rectifying OHS problems respectively. The third columns present the categories emerging from these common descriptions. Columns four and five present the sub themes and the emergent themes developed.

\section{Elements of Experience}

The elements of experience were characterised by two emergent themes emerged for the owner/managers' and employees' understanding of work environment problems: i. Physical safety problems such as slips, falls, cuts and burns and ii. Food safety problems e.g. cleanliness, food going off or food not being cooked properly, Table 1.

Table 1: Owner/managers' and employees' understanding of the Elements of Experience

\begin{tabular}{|c|c|c|c|c|}
\hline \multicolumn{2}{|c|}{$\begin{array}{c}\text { Description of OHS problems characterising Elements of } \\
\text { Experience }\end{array}$} & \multirow[t]{2}{*}{ Categories } & \multirow[t]{2}{*}{ Sub themes } & \multirow[t]{2}{*}{ Themes } \\
\hline Owner/managers & Employees & & & \\
\hline $\begin{array}{l}\text { - No mats on floor, } \\
\text { slippery floor }\end{array}$ & - Spill, slippery floors & \multirow{2}{*}{$\begin{array}{l}\text { Physical } \\
\text { conditions as } \\
\text { Hazards }\end{array}$} & \multirow{5}{*}{$\begin{array}{l}\text { - Physical } \\
\text { hazardous } \\
\text { conditions and } \\
\text { equipment }\end{array}$} & \multirow{7}{*}{$\begin{array}{l}\text { - Physical } \\
\text { safety } \\
\text { problems }\end{array}$} \\
\hline $\begin{array}{l}\text { - We do have messy } \\
\text { services, it does get } \\
\text { messy }\end{array}$ & $\begin{array}{l}\text { - Work benches bit chaotic and no } \\
\text { space }\end{array}$ & & & \\
\hline - Knives & $\begin{array}{l}\text { - Sharp knives, murky water in the } \\
\text { dish wash, }\end{array}$ & \multirow[t]{3}{*}{$\begin{array}{l}\text { - Equipment as } \\
\text { hazards }\end{array}$} & & \\
\hline - Hot stuffs in the sink, & - Something hot, hot pans, deep fry, & & & \\
\hline - Damaged electrical & - Blender, mixture & & & \\
\hline - & - Slip and fall, tip over something & \multirow{2}{*}{$\begin{array}{l}\text { - Physical } \\
\text { Injuries and } \\
\text { incidents }\end{array}$} & \multirow{2}{*}{$\begin{array}{l}\text { - Risks of } \\
\text { physical injuries } \\
\text { to employees }\end{array}$} & \\
\hline - Burns, cuts & $\begin{array}{l}\text { - Cuts, bad cuts, burns, few burns, } \\
\text { little slicing on the hand }\end{array}$ & & & \\
\hline - Cleanliness, hygiene & $\begin{array}{l}\text { - Washing hands, cross } \\
\text { contamination, }\end{array}$ & $\begin{array}{l}\text { - Food } \\
\text { contamination }\end{array}$ & \multirow{2}{*}{$\begin{array}{l}\text { - Problems } \\
\text { associated with } \\
\text { food preparation }\end{array}$} & \multirow{2}{*}{$\begin{array}{l}\text { - Food } \\
\text { safety } \\
\text { problems }\end{array}$} \\
\hline $\begin{array}{l}\text { - Food going off, food } \\
\text { not cooked properly, }\end{array}$ & & $\begin{array}{l}\text { - Food } \\
\text { processing }\end{array}$ & & \\
\hline
\end{tabular}

Physically experienced conditions of work such as slippery floors, chaotic workbenches; equipment such as sharp knives, deep fryers, hot pans; combination of conditions of work and equipment such as hot trays in the sink (causing risks of burns), sharp knives in murky water (causing risks of cuts), spills on floors, floors without mats (potentially causing risks of slips and falls) are explicitly mentioned as OHS problems by both the owner/manager and employee groups. They also unanimously reported hygiene, cross contamination of food or food going off as what they conceive as the other work environment problems.

\section{Elements of Causal Relation}

Three themes emerged for owner/managers' and employees' understanding of the causes behind the OHS problems, Table 2. These are: i. Job inherence: OHS problems are conceived of as an inherent part of the job as when the owner/manager and employees become busy with the job cuts, burns and spills are accepted as part of what is done as a job, ii. Common sense causation: thinking of the do's and don'ts in the kitchen, such as not venturing off while using a sharp knife or using a tea towel to hold hot things, and iii. Breach of norms: for example not wearing flat shoes at work or not letting each other know about imminent hazards such as spills.

Time pressure when preparing food orders and serving the customers as early as possible makes owner/manager and employees so busy that they consider the work environment problems as part of their job and therefore, conceive 'job inherence' as the causal relation behind the problems.

As exemplified by an employee, '...when you're busy and you're so busy that you've got to think about ten to twenty things at once while you're doing it and doing the job.... but not only that just your brain is going so fast and you forget that you've put something down and it's still hot. So, you grab it without even thinking. And you know you burn yourself, but it's nothing major' or 'we do get a few burns. Yeah but I mean that's all part and parcel of the job and the moves'.

Common sense causation as having a causal relation behind the OHs problems is reported by an employee as 'Otherwise, it's so common sense. You know that oil is very hot and the fry, knives and machinery, the mixture, the blenders, they can hurt you real fast. So, it's all about being smart, being responsible'. Similar view has been reported by the owner/manager as, '... You kind of know 
Table 2: Owner/managers' and employees' understanding of the Elements of Causal Relation

\begin{tabular}{|c|c|c|c|c|}
\hline \multicolumn{2}{|c|}{$\begin{array}{c}\text { Description of causal relation behind OHS problems } \\
\text { characterising Elements of Casual Relations }\end{array}$} & \multirow[t]{2}{*}{ Categories } & \multirow[t]{2}{*}{ Subthemes } & \multirow[t]{2}{*}{ Themes } \\
\hline Owner/manager & Employees & & & \\
\hline $\begin{array}{l}\text { - It is very difficult to do a } \\
\text { busy service without being } \\
\text { messy, food scraps going } \\
\text { here and there. }\end{array}$ & $\begin{array}{l}\text { - really busy, spill something and } \\
\text { can't clean it up straightaway } \\
\text { - You've got to think about } \\
\text { twenty things at once doing the } \\
\text { job. } \\
\text { - When busy they grab things } \\
\text { probably knowing that it is hot } \\
\text { but not realising it at the time. }\end{array}$ & $\begin{array}{l}\text { - Too busy to } \\
\text { think of } \\
\text { OHS risks }\end{array}$ & $\begin{array}{l}\text { - Work } \\
\text { environment } \\
\text { problems } \\
\text { inherent to } \\
\text { the job }\end{array}$ & $\begin{array}{l}\text { - Job } \\
\text { inherence }\end{array}$ \\
\hline $\begin{array}{l}\text { - Burns are just the part of the } \\
\text { job } \\
\text { - You are not going to play } \\
\text { rugby without grazing your } \\
\text { knees }\end{array}$ & $\begin{array}{l}\text { - that's all part and parcel of the } \\
\text { job and the moves }\end{array}$ & $\begin{array}{l}\text { - Part of the } \\
\text { job }\end{array}$ & & \\
\hline $\begin{array}{l}\text { - If someone, for example, is } \\
\text { cooking and he grabs a pan } \\
\text { and he burns himself, next } \\
\text { time he will use his } \\
\text { common sense to have a } \\
\text { cloth instead }\end{array}$ & $\begin{array}{l}\text { - that was partly mine fault, I } \\
\text { didn't use tea towel } \\
\text { - Got to make sure my space is } \\
\text { clear for new dishes } \\
\text { - Being distracted by other things } \\
\text { - Off venturing and you're using } \\
\text { sharp knife, it'll cut you bad. } \\
\text { - Concentration and the vision a } \\
\text { major factor. } \\
\text { - Dishes make water murky and } \\
\text { you've to keep it changing }\end{array}$ & $\begin{array}{l}\text { - Individual } \\
\text { needs to } \\
\text { think, make } \\
\text { sure or } \\
\text { concentrate }\end{array}$ & $\begin{array}{l}\text { - Common } \\
\text { sense as the } \\
\text { cause behind } \\
\text { the problems }\end{array}$ & $\begin{array}{l}\text { - Common } \\
\text { sense } \\
\text { causation }\end{array}$ \\
\hline $\begin{array}{l}\text { - You don't go running in the } \\
\text { kitchen if it's slippery. } \\
\text { - If he grabs a pan and burns, } \\
\text { next time he will have a } \\
\text { cloth } \\
\text { - It's all common sense } \\
\text { really. }\end{array}$ & $\begin{array}{l}\text { - Because it is the hot area and } \\
\text { it's just common sense } \\
\text { basically. } \\
\text { - You know the dos and don'ts } \\
\text { you don't run round carrying } \\
\text { knife. }\end{array}$ & $\begin{array}{l}\text { - Common } \\
\text { sense }\end{array}$ & & \\
\hline $\begin{array}{l}\text { - Just telling them this is what } \\
\text { you have to do; this is how } \\
\text { you do it; don't do this way; } \\
\text { the reason why is because } \\
\text { this will happen. }\end{array}$ & $\begin{array}{l}\text { - Accidents brought up by bit } \\
\text { reluctance to say 'behind' } \\
\text { - Chance that someone's put a } \\
\text { knife in and forgets to tell } \\
\text { - Spills, no one's told you, you } \\
\text { probably fall over and hurt } \\
\text { yourself. }\end{array}$ & $\begin{array}{l}\text { - Expectations } \\
\text { around } \\
\text { Communicat } \\
\text { ion } \\
\text { exchanges. }\end{array}$ & $\begin{array}{l}\text { - Norms and } \\
\text { expectations }\end{array}$ & $\begin{array}{l}\text { - Breach of } \\
\text { norms }\end{array}$ \\
\hline $\begin{array}{l}\text { - Make sure girls are wearing } \\
\text { flat shoes not high heel } \\
\text { shoes. } \\
\text { - Food going off, due to not } \\
\text { rotating cooked food or raw } \\
\text { food }\end{array}$ & - & $\begin{array}{l}\text { - Norms of } \\
\text { practice }\end{array}$ & & \\
\hline
\end{tabular}

what you should and shouldn't be doing, you know. And I guess with a little bit of training they just make sense to them. You know, you don't this or you do it this way and things like that. So, ... but also I mean, you know, if Evan, for example, is cooking and he grabs a pan and he burns himself, next time he will use his common sense to have a cloth instead'.

'Breach of norms as one of the causal relation behind OHS problems has been reported by an employee as '.... it's not on purpose to have accidents but it is things that could be brought up here or produced by bit reluctance to say 'behind' or 'around here'. Similarly, the owner/manager noted that 'specially in the food business is food not being cooked properly, food going off, .. a lot of it due to the stock rotation is that not rotating cooked food or paired food or even the raw food that is perishable and not rotating them and there is always the health issue there and health risks...'.

\section{Elements of Legitimisation}

Four themes emerged in relation to the owner/managers' and employees' understanding of the arguments legitimising to bring into attention the OHS problems in the wider context of the work environment, Table 3. 
Table 3: Owner/managers' and employees' understanding of the Elements of Legitimisation

\begin{tabular}{|c|c|c|c|c|}
\hline \multicolumn{2}{|c|}{$\begin{array}{l}\text { Description of arguments legitimising bringing up OHS } \\
\text { problems characterising the Elements of Legitimisation }\end{array}$} & \multirow[t]{2}{*}{ Categories } & \multirow[t]{2}{*}{ Subthemes } & \multirow[t]{2}{*}{ Themes } \\
\hline Owner/manager & Employees & & & \\
\hline $\begin{array}{l}\text { - No major injuries that } \\
\text { somebody been to } \\
\text { hospital }\end{array}$ & $\begin{array}{l}\text { - I don't think we had any major } \\
\text { accidents at work. } \\
\text { - Had no major incident that had } \\
\text { to have ACC or time off work } \\
\text { - No one cut majorly to incur like } \\
\text { stitches or anything like that }\end{array}$ & $\begin{array}{l}\text { - No major } \\
\text { incidents or } \\
\text { accidents }\end{array}$ & $\begin{array}{l}\text { - Majority/mino } \\
\text { rity of } \\
\text { incidents }\end{array}$ & $\begin{array}{l}\text { - Severity of } \\
\text { consequenc } \\
\text { es }\end{array}$ \\
\hline $\begin{array}{l}\text { - I mean I hardly ever } \\
\text { burnt myself. } \\
\text { - Hot stuff goes into the } \\
\text { sinks, they don't burn } \\
\text { themselves. }\end{array}$ & $\begin{array}{l}\text { - None that I think big. I mean we } \\
\text { get the odd, we would. } \\
\text { - Had a few people burnt but like } \\
\text { that, it wasn't a very big deal }\end{array}$ & $\begin{array}{l}\text { - No burns with } \\
\text { significant } \\
\text { consequence }\end{array}$ & $\begin{array}{l}\text { - Significant } \\
\text { consequence }\end{array}$ & \\
\hline - & $\begin{array}{l}\text { - Didn't want to put that across as } \\
\text { I was weak or complaining }\end{array}$ & $\begin{array}{l}\text { - No blame on } \\
\text { me }\end{array}$ & $\begin{array}{l}\text { - Internal to the } \\
\text { person }\end{array}$ & $\begin{array}{l}\text { - Internality/e } \\
\text { xternality of }\end{array}$ \\
\hline $\begin{array}{l}\text { - My thinking is that as } \\
\text { long as the job's done, I } \\
\text { don't mind }\end{array}$ & - & $\begin{array}{l}\text { Job not } \\
\text { hampered }\end{array}$ & $\begin{array}{l}\text { External to job } \\
\text { performance }\end{array}$ & \\
\hline $\begin{array}{l}\text { - The general standard we } \\
\text { have to have to sustain } \\
\text { the business. } \\
\text { - Keep customers happy } \\
\text { - Staffs not washing their } \\
\text { hands, customers eating } \\
\text { off dirty plates }\end{array}$ & $\begin{array}{l}\text { - Make sure that we're off the } \\
\text { scratch, up to the standard. } \\
\text { - Inspection from the city council, } \\
\text { check everything's hygienic. } \\
\text { - They assess your workplace } \\
\text { - Health inspection, make sure } \\
\text { that everything is clear, kept } \\
\text { clean }\end{array}$ & $\begin{array}{l}\text { - Council } \\
\text { inspection and } \\
\text { certification }\end{array}$ & $\begin{array}{l}\text { - Compliance } \\
\text { and } \\
\text { certification }\end{array}$ & $\begin{array}{l}\text { - Compliance } \\
\text { and } \\
\text { certification }\end{array}$ \\
\hline $\begin{array}{l}\text { - Make sure that they are } \\
\text { thanked, recognised. }\end{array}$ & $\begin{array}{l}\text { - So, to look out for the people } \\
\text { safety as well as your own. } \\
\text { - it's just an 'our workplace', } \\
\text { everybody cares about each } \\
\text { other } \\
\text { - Look out for each one, small } \\
\text { slip could lead to big accident }\end{array}$ & $\begin{array}{l}\text { - Care for other } \\
\text { people }\end{array}$ & $\begin{array}{l}\text { - social } \\
\text { exchange }\end{array}$ & $\begin{array}{l}\text { social } \\
\text { exchange }\end{array}$ \\
\hline $\begin{array}{l}\text { - Make sure that } \\
\text { everybody is safe in } \\
\text { their work environment. } \\
\text { - If they are not no reason } \\
\text { why they would want to } \\
\text { work for you. } \\
\text { - Floor over slippery, } \\
\text { damaged electrical or the } \\
\text { ovens aren't working, } \\
\text { people aren't going to be } \\
\text { at work. }\end{array}$ & - & $\begin{array}{l}\text { - Obligation to } \\
\text { ensure safe } \\
\text { and healthy } \\
\text { work } \\
\text { environment }\end{array}$ & & \\
\hline
\end{tabular}

These are: i. Severity of the consequence, whether the consequence of an event is mentally assessed as major or minor in terms of injuries, cost or absence from work, ii. Internality/externality of issues, whether an issue related to OHS risks is likely to raise individual blame or affect job performance, iii. Compliance and certification, and iv. Social exchange, expressed as mutual expectations of ensuring health and safety of one another in the workplace.

Owner/manager and employees are found to understand 'severity of consequences' as an argument for bringing up or not brining up OHS problems for wider attention. Mental assessment whether injuries themselves or associated consequences such as medical costs or compensation are major or minor influences whether or not the conceived physical conditions, equipment and risks are brought to attention in the broader context. As said by the owner/manager, '... You can have little accidents but general health and safety I think we're pretty good... we've been open nearly a year and a half. We've had no major injuries that somebody slipped on the floor and been in or gone to hospital or anything like that'. Identical opinion is given by employees as for example, '.. no one here had really cut himself majorly to incur like stitches or anything like that or you know I think we all had the nips in our fingers ... we haven't had any major incident where someone's had to have ACC or time off work for through cutting themselves or burning themselves or whatever'. 
Internality versus externality of an issue is another argument the owner/manager and employees are found to consider as a reason for whether or not to raise OHS problems. For example, as said by a manager, '.. if I am here they are a little more relaxed ... My thinking is that as long as the job's done, I don't mind'. Internality/externality of issue is equally a strong reason for employees to raise OHS issue, for example, '... there's some gourmet potato in the oven ... And they needed them out. Reuben's like he couldn't I held my hand and grabbed them out. And because everything was kind of bit chaotic, there was not really any bench space or anything to put it. So I ended up holding it and burning my hand away. But I didn't want to drop it on the ground.... I did not really tell anyone that night because I really didn't want to be put that across as I was weak or like that I was complaining about it or I wanted to get out of job or anything'.

Owner/manager consider compliance and certification as an important reason for bringing up OHS problems for wider attention. For example the manager responded, 'she (health and safety inspector) could come at any time and sort of kitchen does need to be to certain standard ... a lot of it comes down to that is that you wanted to a certain standards ... we're just aware that there is the standard we have to have for us to be open. And to sustain the business' or as put strongly by the owner '.... you have to make sure that everything you do is good because if it is not then you can easily just get sued or sort of taken to court for whatever negligence you have..'. Employees equally understand compliance and certification as an important argument for bringing up OHS problems for broader attention, for example, 'they (inspectors) come round and they have a look at everything ....they just turn up .... they just basically assess your workplace... they come in at a certain time where it should have really been messy. And if it is there're problems ... catching people off guard ... They can close you down and it can ruin your business. ... They come in and make sure that we are off the scratch and up to the standard'.

Social exchange owing to the social obligation to ensure the health and safety of each other is found to be a stronger argument for raising OHS problems for wider attention. As noted by owner/manager '... you have to make sure that everybody is safe in their work environment. Because if they are not I mean no reason why they would want to work for you. You know if the floor is over slippery, if the electrical are damaged or something like that and the ovens aren't working and trying to light them all the time with flames and something like that and you know people aren't going to be at work because they say why should we work in this environment?'. Similarly, as mentioned by an employee 'rather it's just the courtesy ... say if I've spilt oil along the floor, then I want everyone know in the kitchen or anyone I would let them know 'hey, I have spilt some oil, it's bit slippery down there. Please just watch, you know'. Or you spill something in the chillers, and I mean you walk in and you slip. I mean no one has told. You don't know and you probably fall over and hurt yourself. But if said 'hey, I've mopped up the chiller floor. Probably it is going to be bit slippery till it dries' ... I think that contributes a lot to the safety of everyone. I mean no one wants to be hurt and no one wants to hurt anybody else .... So, to look out for the people safety as well as your own .... That contributes big to not having any major accidents and not people getting severely injured, which in this industry is possible and probable ... I think it's just an 'our workplace', everybody cares about each other'.

\section{Elements of Action}

Two themes emerged for the owner/managers and employees in terms of their understanding of the elements of action, Table 4. These are: i. Explicit organizational element of action, exemplified as code of conduct, standard, guidelines and training at organizational level and ii. Implicit individual element of action, such as learning from mistakes, letting people know of hazards such as hot pans or knives in certain areas or reminding each other of safe ways of doing things at an individual level.

Owner/manager and employees, both conceive internal standards of practice, compliance action and formal training as the obvious element of action in place to remedy the conceived OHS problems. As exemplified by the employees 'having standards, safe standards that usually we've got to follow' for which the strategy is to 'Knowing to acknowledge how long something had been there before it's started going off and knowing when food is rough or you know that's why we date and label everything'. Similar understanding in relation to action on work environment problems and the drive behind it have been expressed by the owner/managers, for example, as said by the manager, 'health and safety wise, food safety wise all our food is labelled. It's all complies' or 'we've got a certain strategy when we clean up after lunch and after dinner. I think it's kind of general...having general standards'. At the individual level, employees and to some extent the owner/manager are found to acknowledge that actions on work environment problems are common sense driven by the norms and expectations of social exchange in the workplace. For example the view of an employee, 'Knowing difference between the right and wrong, and what's acceptable and what's not' is in congruence with the view of the manager as, 'You kind of know what you should and shouldn't be doing.... Always grab a fry pan with a cloth, it is generally hot...that's just have with you a tea towel like this one I always wear on my shoulder... it's common sense'.

The common sense approach to OHS risks is seen to be reinforced by the norms and expectations of social exchange and also adhering to unwritten rules. For example, 'they would bring it over and put in the sink and tell me it's a hot pan, HOT pan and spray it off to cool down' or 'when you're walking behind the cooks by the stoves you say 'behind'. And they do the same for each other as well' and 'When the chefs are cooking and they have got hot pans they would put that in a certain area. So, the dish hand knows they are hot'. 
Table 4: Owner/managers' and employees' understanding of the Elements of Action

\begin{tabular}{|c|c|c|c|c|}
\hline \multicolumn{2}{|c|}{$\begin{array}{c}\text { Description of course of action remedying OHS problems } \\
\text { characterising Elements of Action }\end{array}$} & \multirow[t]{2}{*}{ Categories } & \multirow[t]{2}{*}{ Subthemes } & \multirow[t]{2}{*}{ Themes } \\
\hline Owner/managers & Employees & & & \\
\hline $\begin{array}{l}\text { - Code of conduct } \\
\text { - Got certain strategy for } \\
\text { clean up after lunch or } \\
\text { dinner } \\
\text { - We date everything we } \\
\text { make in small containers }\end{array}$ & $\begin{array}{l}\text { - Safe standards, guidelines } \\
\text { and form that we've got to } \\
\text { follow. } \\
\text { - Acknowledge how long } \\
\text { something had been there. } \\
\text { - That's why we date and } \\
\text { label everything. }\end{array}$ & $\begin{array}{l}\text { - Internal } \\
\text { standard of } \\
\text { practice }\end{array}$ & $\begin{array}{l}\text { - Internal } \\
\text { standard of } \\
\text { practice }\end{array}$ & $\begin{array}{l}\text { - Explicit } \\
\text { organizational } \\
\text { element }\end{array}$ \\
\hline $\begin{array}{l}\text { Food is labelled. } \\
\text { - Things like food hygiene } \\
\text { certificates everybody has } \\
\text { to have them. }\end{array}$ & $\begin{array}{l}\text { Food handling certificate for } \\
\text { anyone working in the } \\
\text { kitchen. } \\
\text { - Produce food list and also } \\
\text { the cleaning list. }\end{array}$ & $\begin{array}{l}\text { - Meeting } \\
\text { external } \\
\text { certification } \\
\text { requirement }\end{array}$ & $\begin{array}{l}\text { - Compliance } \\
\text { action }\end{array}$ & \\
\hline $\begin{array}{l}\text { - We have an induction. } \\
\text { - Actually the whole job } \\
\text { will be explained to them. } \\
\text { - The majority of the people } \\
\text { in go formal training }\end{array}$ & $\begin{array}{l}\text { - Chefs show you how to } \\
\text { quicken things. } \\
\text { - Front of house, the managers } \\
\text { train the staff } \\
\text { - You've got to be really on to } \\
\text { it, it all begins at training }\end{array}$ & $\begin{array}{l}\text { - Training in } \\
\text { place }\end{array}$ & $\begin{array}{l}\text { Formal } \\
\text { training }\end{array}$ & \\
\hline $\begin{array}{l}\text { - If the chef is cooking and } \\
\text { he grabs a pan and he } \\
\text { burns himself, next time } \\
\text { he will use his common } \\
\text { sense to have a cloth } \\
\text { instead. } \\
\text { - Just you learn. So, it's not } \\
\text { worth the pain. }\end{array}$ & $\begin{array}{l}\text { - Burn yourself a few times } \\
\text { you soon reckon not to do it } \\
\text { again } \\
\text { - I am just getting better and } \\
\text { better and better as it goes. }\end{array}$ & $\begin{array}{l}\text { - Learning from } \\
\text { mistakes }\end{array}$ & $\begin{array}{l}\text { - Learning } \\
\text { from } \\
\text { mistakes }\end{array}$ & $\begin{array}{l}\text { - Implicit } \\
\text { individual } \\
\text { element }\end{array}$ \\
\hline $\begin{array}{l}\text { There is a lot of ho stuff } \\
\text { goes into the sinks and } \\
\text { they are aware that that's } \\
\text { hot and they don't tend to } \\
\text { burn themselves. }\end{array}$ & $\begin{array}{l}\text { - Stay away from the chefs if } \\
\text { they are cooking } \\
\text { - Stay away from the food if } \\
\text { you're not using them } \\
\text { - Hot pans are put in a certain } \\
\text { area, dishies know they're } \\
\text { hot } \\
\text { - Everything that goes into the } \\
\text { right sink is always hot. }\end{array}$ & - unwritten rules & $\begin{array}{l}\text { - Unwritten } \\
\text { rules }\end{array}$ & \\
\hline - & $\begin{array}{l}\text { - Tell 'hot pan', 'HOT pan' or } \\
\text { spray it off to cool down. } \\
\text { - Remind each other to always } \\
\text { use a tea towel. } \\
\text { - Get floor cleaned up as } \\
\text { quickly as possible. } \\
\text { - Look out for people's safety } \\
\text { as well as your own }\end{array}$ & $\begin{array}{l}\text { Norm of social } \\
\text { expectations }\end{array}$ & $\begin{array}{l}\text { - } \text { social } \\
\text { exchange }\end{array}$ & \\
\hline $\begin{array}{l}\text { - Watching, checking to } \\
\text { make sure things is done } \\
\text { properly. } \\
\text { - Just as you are going } \\
\text { along tell them you do it } \\
\text { this way }\end{array}$ & $\begin{array}{l}\text { - When walking behind } \\
\text { someone say 'behind' as a } \\
\text { safety thing. } \\
\text { - Just to see or know where } \\
\text { everyone is. } \\
\text { - Just definitely letting people } \\
\text { know where you are. }\end{array}$ & $\begin{array}{l}\text { - Communication } \\
\text { as a norm of } \\
\text { social exchange }\end{array}$ & & \\
\hline $\begin{array}{l}\text { - Always grab a fry pan } \\
\text { with a cloth, it is generally } \\
\text { hot. } \\
\text { - You kind of know what } \\
\text { you should and shouldn't } \\
\text { be doing }\end{array}$ & $\begin{array}{l}\text { - You go by the common } \\
\text { sense. } \\
\text { - Knowing difference between } \\
\text { the right and wrong }\end{array}$ & $\begin{array}{l}\text { - common sense } \\
\text { approaches }\end{array}$ & $\begin{array}{l}\text { - Common } \\
\text { sense } \\
\text { approach }\end{array}$ & \\
\hline
\end{tabular}




\section{Discussion}

The finding that the owner/manager and employees consider physical aspects of the work environment as the main OHS problems is in congruence with the findings by Jensen (2002). It could be argued that, for both the owner/manager and employees, physical problems and the risks associated with such problems are visibly obvious, easily perceptible and implications of such problems are discernibly evident. This possibly has facilitated the development of a shared understanding of physical aspects as the work environment problems.

Though the causal relations behind the problems are found to be linked to the employees themselves as reported in some of the previous studies (Gardner, et al., 1999; Hasle, et al., 2009; Holmes \& Gifford, 1997)), common sense causation and breach of social norms are the particular causal relations the owner/manager and employees identify with the conceived work environment problems. Both owner/manager and employees are found to accept work environment problems as inherent to the job and thus tend to exhibit fatalistic resignation to the OHS risks (Hasle, et al., 2009). Interestingly, employees are found to consider not only the risks of cuts and burns associated with physical hazards, but also the risks of stress associated with working under time pressure as 'part and parcel' of the job, corroborating with previously reported (Hasle \& Limborg, 2006) risk acceptance nature of employees.

In congruence with the findings of Jensen (2002), compliance and certification, such as food handling certificates checked by the city council or the food and hygiene certificate issued by it, legitimises the reason for employees to bring up any work environment problem in the wider context. In order to be able to meet such certification requirements any issue likely affecting it is brought up in the wider context and is accepted as an issue for discussion and action by owner/managers and employees.

Equally influential argument legitimising discussion of work environment problems in the wider context are norms and expectations associated with social exchanges in the workplace. Even if the SB owner/managers are less knowledgeable of their legal obligations toward ensuring health and safety of the employees in the workplace (Laird, Olsen, Harris, Legg, \& Perry, 2009), the social exchange expectations seem to play a bigger role in acceptance of the legitimacy of OHS risks in the workplace. This could be because the social groups, in the context of small businesses, tend to have closer reciprocal relations (Hasle, et al., 2009) and low polarisation of interests (Eakin \& MacEachen, 1998), which presumably provides social context for reciprocal exchange of opinions identify common goals including that around OHS problems.
By definition, social exchange is the process of exchange of transactions between social groups or individuals induced by reciprocal reward expectations (Parzefall \& Salin, 2010; Zafirovski, 2003). Such exchanges, which could involve economic rewards or non-economic relational transactions (Blau, 1964; Chadwick-Jones, 1976; Ekeh, 1974; Parzefall \& Salin, 2010) occur in the absence of any formal norms, rules and values of the exchange in place, and the social groups implicitly apply understood norms to the situation of social exchange at that moment (Ekeh, 1974; Parzefall \& Salin, 2010). It, therefore, seems that unwritten reciprocal expectations out of social exchange have played an important motivational role in bringing to notice the OHS risks in the wider context, thus exhibiting mutual social behaviour around OHS problems. This appears to be in contrast to the finding of the study by Jensen (2002) where explicit legislative demands were reported to be playing an important role in legitimising OHS issues.

Severity of consequences and internality/externality of issues seem to be the other arguments influencing bringing up or not bringing up work environment problems. It seems that mental assessment of the severity of the consequences and internality/externality of issues determines whether or not to bring OHS problems into broader attention. Severity of consequences relates to whether the OHS problem, in case of an event will have a major or minor outcome. Usually any work environment problem that the owner/manager or employees consider minor in terms of consequences, such as injuries, medical care or absences from work are not brought up for wider attention.

The internality of the issue relates to whether or not the issue in question is seen as an outcome of individual action which could possibly lead to someone being blamed for its causation or being reprimanded for it. The externality of the issue relates to whether or not the issue is seen as more likely affecting the overall objective of job accomplishment and is less likely to be a reason for blame to be laid on the individual. It is found that employees understand the internality of the issue as an argument for not bringing up OHS problems in the wider attention. This supports the blame avoidance attitude of employees when it comes to bringing up OHS issues in wider context (Hasle, et al., 2009). Whereas owner/manager understand the externality of the issue as an argument for bringing up the OHS problems for wider attention. As found by Jensen (2002), generally externality of OHS issues legitimises the reason for bringing up for discussion whereas internality of OHS issues for not brining up for discussion.

Unlike the findings of Jensen (2002), both the owner/manager and employees conceive explicit organizational elements of action as the main course of action on work environment problems. However, compliance with food hygiene practice and certification is seen as the main driver behind the explicit 
organizational elements of action, which supports the findings of the study by Laird et.al. (2009) of hairdressers where the driver for OHS practice was meeting compliance and certification of public health and hygiene requirements. Meeting food safety compliance and hygiene certification requirements for which the organization has to maintain certain standards of practice and follow strategies, necessitates taking action on work environment problems as acknowledged by the owner/manager and employees equally. These Elements of action are explicit as they are known and visible to everyone and occur as organizational standard of practice. However, employees equally conceive implicit individual elements of action as the other driver for action on remedying work environment problems. The implicit individual element of action pertains to what the owner/manager and employees consider is remedying the OHS problems at the individual level. Employees, and to some extent owner/managers, are found to acknowledge that actions on work environment problems are primarily common sense, and are driven by the norms and expectations of social exchange in the workplace. People in the workplace commonly expect reciprocal exchanges of alerts on OHS hazards and risks as a norm and expectation of social exchange. Similarly, unwritten but understood rules also play an important role in control of OHS risks.

As such, having discussed the shared understanding of OHS risks, an important direction for future research could be how development of a shared understanding of OHS risks occurs, what influences such occurrences and any pre-requisites facilitating the development of a shared understanding of OHS risks particularly in restaurants and cafe and broadly in other sectors of small business.

\section{Limitations of the study}

This paper is part of a multiple case study which is still underway. The results do not include analysis of data from ethnographic field observation, which was used as the other data collection technique in the study. In relation to data analysis, only the initial coding of data responses was done using NVivo software. The remaining steps of analysis were done manually in MS Word.

\section{Conclusion}

The study showed that the owner-manager and employees in the single case small restaurant and cafe business in New Zealand have a shared understanding of OHS problems, causal relation behind the problems, arguments legitimising bringing up of the problems and the course of action to rectify the problems. Both the owner-manager and employees consider physical safety and food safety problems of concern in their work environment. Though the owner-manager and employee groups accept job inherence as one of the causes behind the problems, both the groups are found to have shared understanding that common sense causation and breach of norms are two main causal relations behind the perceived OHS problems. Assessment of severity of consequences and internality/externality of issues, demands of compliance and certification, and social exchange expectations are four arguments that both the social groups consider to be the reason for legitimising to bring up OHS problems for wider attention. Both groups also have shared understanding that explicit organizational element of action, constituting of internal standard of practice, compliance action and formal training, has major role in remedying OHS risks. It is also found that the groups have a shared understanding that implicit individual element of action comprising of learning from mistakes, unwritten rules, social exchange and common sense approach at the individual level equally contribute towards remedying OHS problems.

Seemingly, for physical aspects of the work environment problems understood as of concern, social exchange seems to be an internal driver and compliance and certification an external driver for the development of shared understanding between the social groups. It is apparent that external agents such as food hygiene inspectors or building safety inspectors have an important role to play in developing a shared understanding of OHS risks and influencing change and intervention towards controlling OHS risks.

\section{REFERENCES}

Blau, P. (1964). Exchange and power in social life. New York: John Wiley \& Sons.

Braun, V., \& Clarke, V. (2006). Using thematic analysis in psychology. Qualitative Research in Psychology(3), 77-101.

Chadwick-Jones, J. K. (1976). Social Exchange Theory: It's structure and influence in social psychology. London: Academic Press.

Champoux, D., \& Brun, J. P. (2003). Occupational health and safety management in small enterprises: An overview of the situation and avenues for intervention and research. Safety Science, 41, 301-318.

Eakin, J. M., \& MacEachen, E. (1998). Health and the social relations of work: a study of the health-related experiences of employees in small workplaces. Sociology of Health adn Illness, 20(6), 896-914.

Ekeh, P. P. (1974). Social Exchange Theory: The Two Traditions. London: Heinemann Educational Books Ltd.

Gardner, D., Cross, J. A., Fonteyn, P. N., Carlopio, J., \& Shikdar, A. (1999). Mechanical 
equipment injuries in small manufacturing businesses. Safety Science, 33, 1-12.

Hasle, P. (2009). Work environment in small firms responses from owner-manager.

Hasle, P., \& Jensen, P. L. (2006). Changing the internal health and safety organization through organizational learning and change management. Human Factors and Ergonomics in Manufacturing, 16(3), 269-284.

Hasle, P., Kines, P., \& Andersen, L. P. (2009). Small enterprise owners' accident causation attribution and prevention. Safety Science, 47(1), 9-19.

Hasle, P., \& Limborg, H. J. (2006). A review of the literature on preventive occupational health and safety activities in small enterprises. Industrial Health, 44, 6-12.

Holmes, N., \& Gifford, S. M. (1997). Narratives of risk in occupational health and safety: why the good 'boss' blames his tradesmand and the 'good' tradesman blames his tools. Australian and New Zealand Journal of Public Health, 21(1), 11-16.

Holmes, N., Triggs, T. J., Gifford, S. M., \& Dawkins, A. W. (1997). Ocupational injury risk in a blue collar, small business industry: Implications for prevention. Safety Science, 25(1-3), 67-78.

Jensen, P. L. (2002). Assessing assessment: experience of worker participation in risk assessment. Economic and Industrial Democracy, 23(2), 201-227.

Kvale, S. (1996). Interviews: An introduction to qualitative research interviewing: Sage Publications.

Laird, I., Olsen, K., Harris, L.-H., Legg, S. J., \& Perry, M. (2009). The development of prevnetive interventions to reduce hazardous chemical exposures in small business in New Zealand. Palmerston North: Massey University.

Lamm, F. (2002). Occupational health and safety in small businesses. In M. Llyod (Ed.), Occupational health and safety in New Zealand contemporary social research (pp. 93-117). Palmerston North: The Dunmore Press.

Legg, S. J., Battisti, M., Harris, L. A., Laird, I. S., Lamm, F., Massey, C. L., et al. (2009). Occupational health and safety in small businesses (No. 12). Wellington: New Zealand National Occupational Health and Safety Advisory Committee.
Lingard, H., \& Holmes, N. (2001). Understandings of occupational health and safety risk control in small businesses construction firms: barriers to implementing technological controls. Construction Management and Economics, 19, 217-226.

Massey, C. (2004). Employee practices in New Zealand SMEs. Employee Relations, 26(1), 94105.

Massey, C. (2005). The size and significance of the small business sector. In C. Masey (Ed.), Entrepreneurship and small business management in New Zealand (pp. 3-16). Auckland: Pearson education.

Mullins, L. J. (1993). The hotel and the open system model of organizational analysis. The Service Industries Journal, 13(1), 1-16.

Parzefall, M. R., \& Salin, D. M. (2010). Perceptions of and reactions to workplace bullying: A social exchange perspective. Human Relations, 63(6), 761-780.

Renn, O. (1992). Concepts of Risk: A Classification. In S. Krimsky \& D. Godlgin (Eds.), Social Theories of Risk (pp. 53-79). Westport: Praeger.

Ryan, R. (1996). Employment relations in hotels, cafes and restaurants: Summary of survey results. Industrial Relations Centre, Victoria University of Wellington.

Sørensen, K. H., \& Sætnan, A. R. (1983). Makt og medvirkning i arbeidsmiljøet. . Norway: Norsk Institutt for sykehusforskning.

Sorensen, O. H., Hasle, P., \& Bach, E. (2007). Working in small enterprises - is there a special risk? Safety Science, 45, 1044-1059.

Walters, D., \& Frick, K. (2000). Worker participation and the management of occupational health and safety: Reinforcing or conflicting strategies? In K. Frick, P. L. Jensen, M. Quinlan \& T. Wilthagen (Eds.), Systematic occupational health and safety management: Perspectives on an international development. Oxford: Pergamon.

Zafirovski, M. (2003). Some amendments to social exchange theory: A sociological perspective. Retrieved 22 February 2010, from http://theoryandscience.icaap.org/content/vol10 04.002/01 zafirovski.html 
